\title{
Zöld növényi biomassza hasznosításának nemzetközi és hazai kilátásai
}

\section{Global and domestic status and prospects of green biomass utilization}

\author{
G. ANTAL \\ Debreceni Egyetem, Gazdaságtudományi Kar, Ágazati Gazdaságtan és Módszertani Intézet, \\ antal.gabriella@econ.unideb.hu
}

\begin{abstract}
Absztrakt. Napjainkban az emberiség energiafelhasználása még a fosszilis energiáktól függ, de a megújuló energiaforrások szerepe egyre inkább erôsödik elsôsorban a fosszilis energiaforrások kimerülése, a környezetvédelmi problémák felértékelődése és a klímapolitikai indokok miatt. A biomassza a világ negyedik legfontosabb energiaforrása, amely globális szinten közel 73\%-ot képvisel a megújuló energiaellátásban. A biomassza felhasználás növekedésének évi üteme azonban meglehetősen elmarad a modern megújuló energiaforrásokhoz képest. A világon található biomassza igen sokrétü, különböző módon elökészíthetőek és feldolgozhatóak. Jelenleg a „zöld kémia” iparágon belül (a kőolaj-alapú, vegyipari szintetikus alapanyagok kiváltása növényi, biomassza eredetű anyagokkal) az eltüzelés, a pirolizálás, a biogáz-, a bioetanol- és a biodízel és a különböző kémiai alapvegyületek elóállitásának van jelentősége. Jelen kutatások célja az egyes megújuló energiaforrások és a biomassza felhasználásának globális és hazai helyzetének bemutatása, a Debreceni Egyetemen folyó kutatási programokban évek óta vizsgált potenciális éveló, lágyszárú biomassza növény, az olasznád (Arundo donax L.) hasznosítási lehetôségeinek ismertetése.
\end{abstract}

Abstract. Nowadays, the energy consumption of global population is depending on fossil fuels, but the role of renewable energies has been increasing rapidly, primarily due to the depletion of fossil fuels, the appreciation of environmental problems and climate policies. Biomass is the fourth most important energy resource in the world, provided an estimated 70\% of global renewable energy supply. However, the annual growth rate of biomass is lagging behind modern renewable energy sources. The type of biomass is very diverse and can be processed and utilised by different methods. Currently, in the "green chemistry" industry (the replacement of petroleum-based, synthetic chemical raw materials with bio-based compounds from plant biomass), the importance of combustion, pyrolysis, biogas, bioethanol, biodiesel and basic chemical compounds production have been increasing. The objectives of the present research is to analyse the global and domestic status of renewable energies and biomass production, furthermore the possibilities of utilization of perennial, herbaceous biomass plant, the giant reed (Arundo donax L.), with which has been conducting research for numerous years at the University of Debrecen. 


\section{Bevezetés}

A növekvő népesség energiaigényeinek kielégítése alapvető kihívás, az élelmiszerek és a víz iránti kereslet növekedése mellett. Jelenleg a Föld népessége elérte a 7,6 milliárd főt, 2050-re több mint 9 milliárd főre is emelkedhet. Napjainkban az emberiség energia szükségletének közel 80\%-át még mindig a fosszilis energiahordozók (szén, kőolaj, földgáz) biztosítják, a negyedik legfontosabb hasznosított energiaforrás a biomassza. A fosszilis energiaforrások kimerülésével, a környezetvédelmi és a klímapolitikai indokok miatt az utóbbi évtizedekben a megújuló energiaforrások közül az ún. modern megújulók (nap, szél, víz, geotermikus, óceáni és áramlási energia) szerepe is fokozatosan növekedett. A fosszilis energiát kísérő szén-dioxid és üvegházhatást okozó gázok kibocsátásának környezeti hatásait egyre inkább érzékelhetjük, az éghajlatunkban végbemenő változások hatással vannak a mezőgazdasági termelési rendszerek átalakulását is eredményezhetik. Jelen kutatások célja a különböző energiaforrások felhasználásának globális, Európai Uniós és hazai helyzetének jellemzése az ezredfordulót követően napjainkig; a megújuló energiaforrások beruházásainak, költségeinek és környezetvédelmi hatásának értékelése a fosszilis energiaforrásokkal szemben; a legfontosabb megújuló energiaforrásokkal szembeni előírások és irányelvek bemutatása; a növényi biomassza alapanyagok típusai és a különböző hasznosítási lehetőségek, a biomassza alapú energiatermelés, a bioüzemanyag előállítása és a bioipari nyersanyagok hasznosítási lehetőségeinek bemutatása. A növényi biomassza hasznosítás területén az egyik potenciális évelő, lágyszárú biomassza növény, az olasznád eddigi hasznosítási lehetőségeit kívánom ismertetni más energianövényekkel történő összehasonlításban.

\section{Globális és hazai energiafelhasználás}

\subsection{A világ és az EU energiatermelése és felhasználása}

A Nemzetközi Energia Ügynökség (IEA - International Energy Agency) adatai alapján, globális szinten 2015-ben a teljes primer energiafelhasználás (TPES - Total Primary Energy Supply) mintegy 13647 Mtoe (mega tonna olaj-egyenértékű) volt, amely megközelítőleg 571,4 EJ (exajoule) energiának felel meg. A fosszilis energiaforrások (kőolaj, földgáz, szén) 81,4\%-al, a nukleáris energia 4,9\%-al és a megújuló energiaforrások mintegy 13,6\%-kal járultak hozzá az energiatermeléshez. A megújuló energiaforrások részesedése emelkedett az energiafelhasználásban, a fosszilis energiaforrások közül a szén és a földgáz részesedése nagyobb mértékben nőtt (1. ábra). 2000-hez képest a teljes energiafelhasználás 36,1\%-al nőtt (+3619 Mtoe), a megújuló energiaforrások mennyisége 42\%-al emelkedett (+1862 Mtoe). A fosszilis energiák közül a leginkább a szén növekedett (66\%-al; +1525 Mtoe), a termelt nukleáris energia mennyisége kisebb mértékben csökkent (0,7\%-al; -670 Mtoe). Globális szinten a legnagyobb népességgel rendelkező, ázsiai kontinensen állították elő a legtöbb energiát, a teljes energiaellátás 46,6\%-át, a fosszilis energiák 49\%-át és a megújuló energiaforrások 43,3\%-át [1]. 

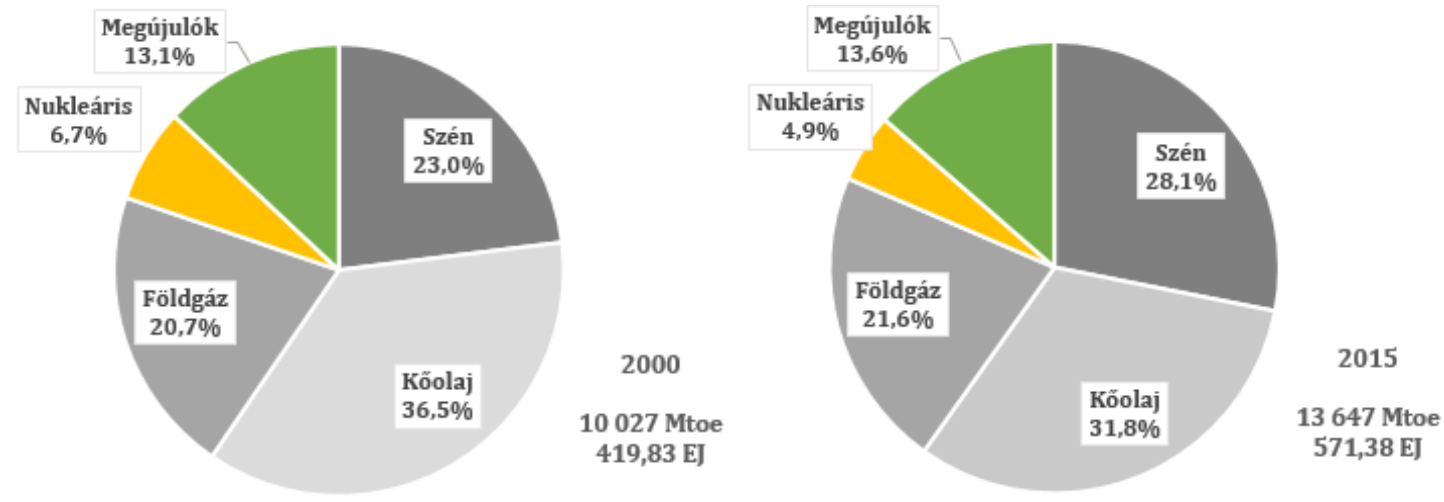

1. ábra: Az egyes energiaforrások részesedése a világ teljes primer energiafelhasználásából 2000 és 2015-ben Forrás: saját szerkesztés, International Energy Agency adatai alapján [2, 3].

A World Bioenergy Association (WBA) nonprofit szervezet legfrissebb adatai alapján 2014-ben a globálisan megtermelt 573 EJ energiából végső felhasználásra 360 EJ energia jutott. Megközelítőleg 37\% a feldolgozásból, a szállításból és az energiaipar saját felhasználásából származó veszteség, amely leginkább a fosszilis energiaforrások átalakítása és hasznosítása során keletkezik. A megtermelt földgáz 39,5\%-át, a szén 53,5\%-át és a kőolaj 24\%-át nem hasznosították, míg a modern megújuló energiaforrások közül a villamos áram termelésre felhasznált nap és szél energia közel egésze végső felhasználásra került (2. ábra). Az energiaforrások kereskedelemében a megújulók nem játszanak nagy szerepet $(0,5 \%$ alatti a részesedés), mert pl.: a szél, nap és víz-energiából származó elektromos áram nagy részét az országon belül használják fel. A megújuló energiaforrásoknak a nemzetközi energiakereskedelemben a bioenergia szektornak, a különböző típusú biomassza alapú tüzelőanyagoknak és a folyékony bioüzemanyagoknak van jelentősége. Hőösszegben kifejezve az ázsiai kontinens a globális energiaimport 48\%-át (104 EJ), az export 36,8\%-át (80,3 EJ) tette ki 2014ben, a kereskedelmük 99,6-99,8\%-át a fosszilis energiaforrások jelentették. A megújulók részesedése egyedül az európai kontinensen haladta meg az 1-2\%-ot a kereskedelemben. 2014-ben az EU-28 tagországa hőösszegben kifejezve (59,4 EJ) másfélszer annyi energiát importált, mint az egész amerikai kontinens (37,7 EJ), és több, mint kilencszeresét az afrikai kontinensnek (6,38 EJ) [4]. 


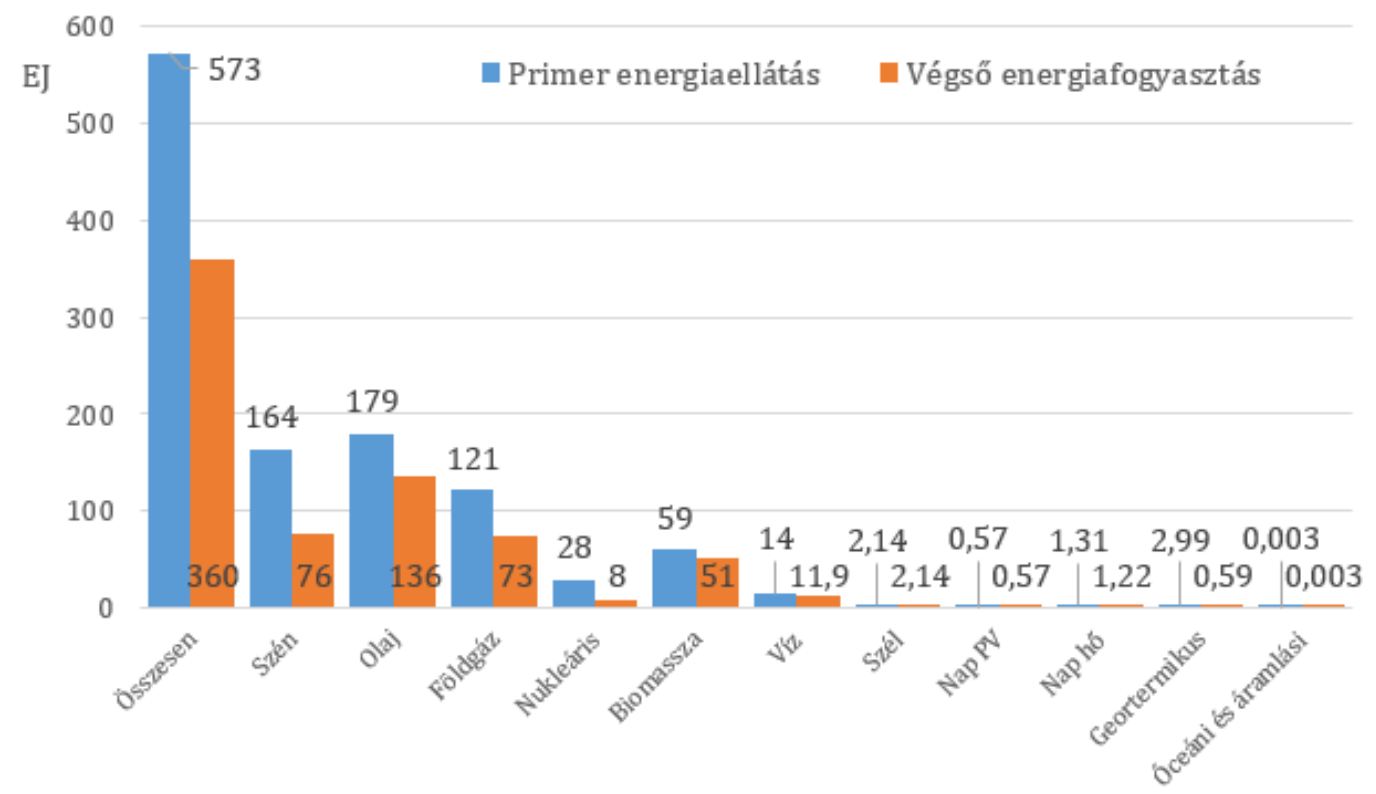

2. ábra: Az egyes energiaforrások globális termelése és végső energiafogyasztása 2014-ben Forrás: saját szerkesztés, World Bioenergy Association adatai alapján [4].

A globális primer energiaellátásból 2014-ben a megújuló energiaforrások tekintetében a legnagyobb arányt, mintegy 73,3\%-ot a különböző típusú bioenergiák (szilárd és folyékony biomassza) tették ki (59 EJ). A vízenergia 17,3\%-al (14 EJ), a geotermikus energia 3,7\%-al (2,99 EJ), a napenergia összesen 2,4\%-al (1,88 EJ), a szél 3,2\%-al és a maradék részt egyéb megújuló energiaforrásokból (pl. óceáni, áramlási energiából) nyerték (3. ábra). 2000-hez képest globális szinten az energiatermelés évente átlagosan 2,2\%-al, a megújulók 2,8\%-al emelkedtek 2014-re. A megújuló energiaszektorban a technológiai innovációnak és a beruházásoknak köszönhetően a villamos energiacélú napenergia felhasználás átlagosan évi 45\%-os, a szélenergia 25,1\%-os ütemben nőtt. Jelentős még a hőtermelésre fordított napenergia, az óceáni és az áramlási energia előállítás növekedése (13,8\% és 4,41\%). A legnagyobb részesedést adó biomassza 2,3\%-al, a legrégebben használt modern megújuló energiaforrás a vízenergia termelés 2,8\%-al nőtt évente átlagosan 2000-hez képest [4]. Az EU-28 tagországában a megújuló energiaforrásokon belül a szilárd biomassza sokkal kisebb részesedésű (46\%), mint globális szinten. A víz (16\%), a szél (10\%), a nap (6\%), az emberi tevékenységből származó hulladék hasznosításán felül (5\%), a biogáz (7\%) és a bioüzemanyagoknak (7\%) van jelentősége [5]. 
Világ

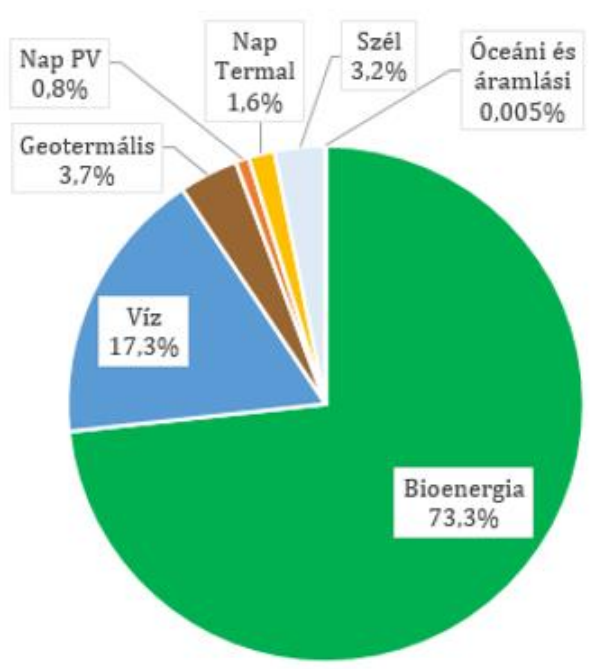

EU-28

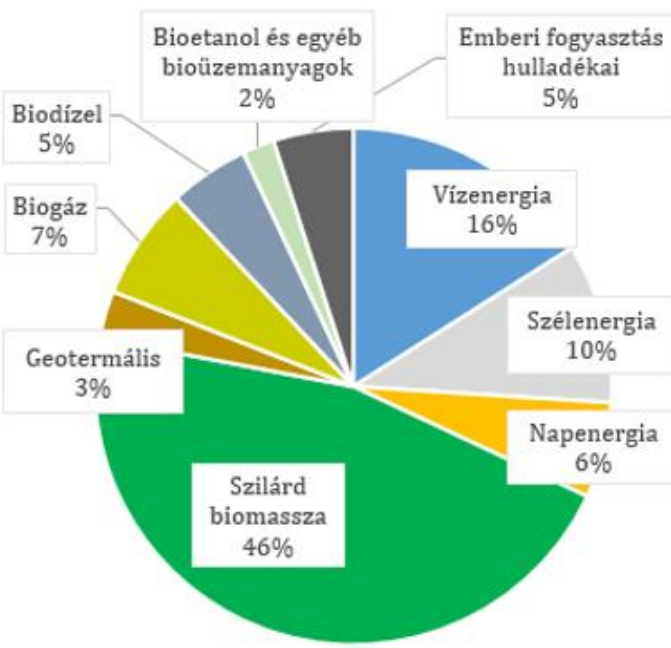

3. ábra: A megújuló energiaforrások megoszlása a primer energiaellátásából a világban és az EU-ban 2014-ben Forrás: saját szerkesztés, World Bioenergy Association és Environment Energy Agency adatai alapján [4, 5].

2015-ben a végső energiafogyasztásban, az emberiség energiaszükségletének 78,4\%-a a fosszilis energiaforrásokból (kőolaj, szén, földgáz) származott. A modern megújuló energiaforrások 10,2\%-al (szél-, nap, víz-, geotermikus-energia, bioüzemanyagok stb.), a tradicionális biomassza 9,1\%-al, a nukleáris energia 2,3\%-al járul hozzá a végső energiafogyasztáshoz. Annak ellenére, hogy a megújuló energiaforrások részesedése folyamatosan emelkedik az egyes felhasználási szektorok energiaszükségleteit még nem a megújuló energiák biztosítják. A modern megújuló energiaforrások közül a hőenergia termelésre felhasznált biomassza, nap és geotermikus energia 4,2\%-ot, a villamos energiatermelésre felhasznált szél, nap, biomassza, geotermikus 1,6\%-ot, a bioüzemanyagok 0,8\%-ot és a vízenergia 3,6\%-ot képviseltek az energiafogyasztásban (4. ábra) [6]. A globális szinten rendelkezésre álló energia közel 50\%-át közvetett vagy közvetlen hőenergiaként, 20\%-át elektromos áramként hasznosítjuk, a közlekedési szektor pedig a megtermelt energia 30\%-át használja fel [4].

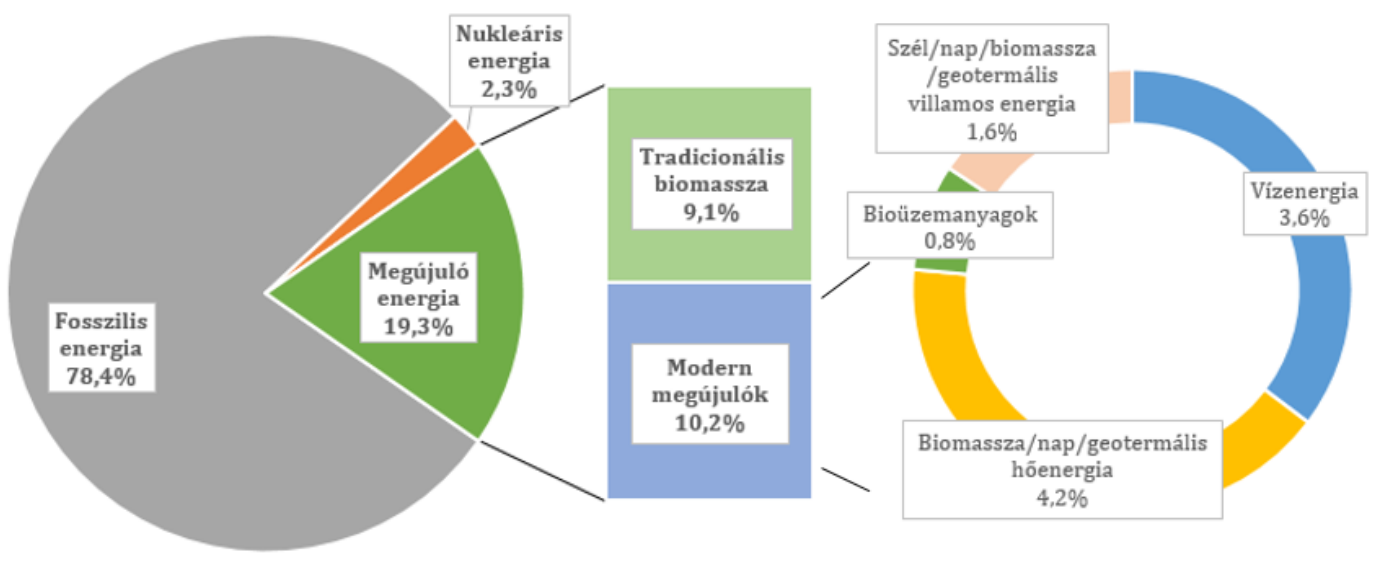

4. ábra: Az egyes energiaforrások részesedése a világ végső energiafogyasztásából 2015-ben Forrás: saját szerkesztés, Renewable Energy Policy Network for the 21st Century adatai alapján [6]. 
2015-ben az EU-28 tagországában mintegy 782 Mtoe ( 32,7 EJ) energiát állítottak elő, a végső primer energiafogyasztás 1084 Mtoe volt ( 45,4 EJ), amely, világosan megmutatja az EU energiafüggését. Az energiatermelésben a nukleáris energia 28,3\%-ban (221,2 Mtoe), a megújuló energia 26,2\%-ban (205 Mtoe), a szilárd tüzelőanyagok 18,6\%-ban (145,4 Mtoe), a földgáz 13,8\%-ban (107,9 Mtoe), a kőolaj 11,4\%-ban (89,3 Mtoe) és a hulladékok és egyéb nem megújulók hasznosítása 1,7\%-ban (13,0 Mtoe) járultak ehhez hozzá [7].

Magyarországon a fosszilis tüzelőanyagok kimerülésével (szén és szénhidrogének) egyre inkább megnőtt a földgáz (14,2\%), a nukleáris $(40,4 \%)$ és a megújuló energiahordozók $(21,5 \%)$ iránti részesedés is. 2015-ben hazánk energiatermelése 472,7 PJ (petajoule) volt, azonban a teljes energiafelhasználása 1000-1100 PJ között változott az utóbbi években, így az energiaigények kielégítésére 2015-ben 756,3 PJ energiát importáltunk [8]. 2016-ban a rendelkezésre álló energia 30,5\%-át a lakosság, a 26,5\%-át a közlekedés, a 24,9\%-át az ipar, a 14,3\%-át a kereskedelem és közcélú szolgáltatások, a 3,7\%-át a mezőgazdaság, erdőgazdálkodás és a halászat használta fel [9].

\subsection{Megújuló energia beruházások és költségek alakulása, a környezetvédelmi vonatkozások jelentősége}

Globális szinten az utóbbi 7 évben az új, megújuló energia-előállítását célzó beruházások meghaladták a 200 milliárd USD-t, 2016-ban 241,6 milliárd USD volt. A beruházások 32\%-a Kínában (78,3 milliárd USD), 25\%-a Európában valósult meg (59,8 milliárd USD). 2015-höz képest 23\%-os csökkenés következett be (312 milliárd USD-ról), de 2016-ban rekord mennyiségű megújuló energia hasznosítást célzó üzem indítását regisztrálták. Ehhez a nagymértékű csökkenéshez az is hozzájárult, hogy elsősorban a napenergia hasznosítást célzó beruházások költségei csökkentek a technológia és az eszközök fejlesztésének köszönhetően. Az elmúlt 10 évben a beruházások közel 90\%-a nap és szélenergia hasznosítása céljából létesültek. A napenergia hasznosítást célzó beruházások értéke 2016-ban 113,7 milliárd USD volt, a kapacitások nagymértékű emelkedése óránként 31000 napelem elhelyezését jelentette globálisan. Dániában a hütésre és fütésre fordított napenergia kapacitás megduplázódott 2016-ban. A világon már 90 országban használnak szélerőműveket villamos áram termelésre. A biomassza és a bioüzemanyag célú beruházások aránya az utóbbi években értékben visszaestek, a vízenergia hasznosítását célzó beruházások értéke hasonló volt az előző évekhez (5. ábra). A beruházások jelentős része, közel 90\%-a támogatásból valósult meg. Fontos kiemelni, hogy a megújuló energiaforrások hasznosításának növekedése mellett a fosszilis vagy nukleáris energia hasznosítását célzó beruházások értéke is jelentős. 2016-ban a fosszilis energiát célzó beruházások értéke 113,8 milliárd USD, a nukleáris energia befektetések 30 milliárd USD volt [6]. 


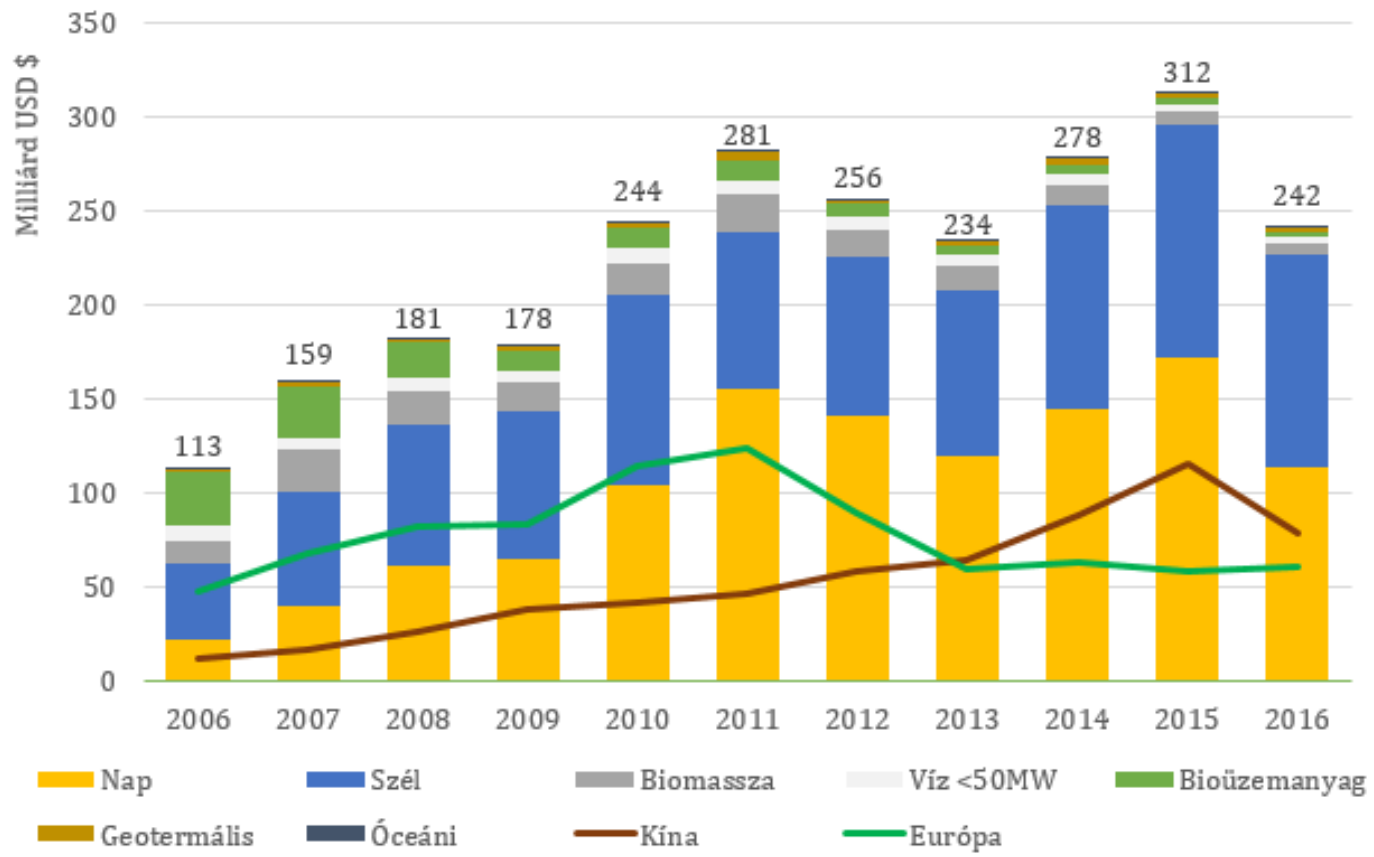

5. ábra: Az egyes megújuló energiaforrások beruházásainak értéke (milliárd USD) 2006-2016 között a világon Forrás: saját szerkesztés, Renewable Energy Policy Network for the 21st Century adatai alapján [6].

A megújuló energiaforrások beruházási- és termelési költségei széles határok között változnak, de sok esetben még magasabbak a fosszilis energiaforrásoktól $[6,10]$. Az International Renewable Energy Agency (IRENA) adatbázisa alapján, a világon megtalálható számos olyan biomassza-, víz-, geotermális- és szélenergia hasznosításra alkalmas üzem, amelyek esetén a KWh-énti fajlagos villamos-energia termelés és beruházás költségei alacsonyabbak a fosszilis energiát használó üzemekkel szemben a szakirodalomban használt LCOE (Levelized Cost of Electricity) képlet értékei alapján. 2017-ben globálisan a villamos energia-termelés költségei 2010-hez képest tovább csökkentek, a vízenergia előállítás átlagos LCOE értékei 0,05 USD/KWh volt és a szélenergia 0,06 USD/KWh-ba került átlagosan. A kalkulációk egyre inkább a versenyképesség és fenntarthatóság irányába való törekvéseket mutatják. 2010-hez képest leginkább a napenergia hasznosítás költségei csökkentek, mintegy 73\%-al a technológia és az eszközök fejlődésének következtében (0,1 USD/KWh). A fosszilis energiák hasznosításával szemben leginkább a víz és a szélenergia versenyképes, de a biomasszából történő villamos áram fejlesztés is felveheti a versenyt, azonban a biomassza termelési és a melléktermékek szállítási költségei miatt nagy határok között változhat az elóállítás költsége (6. ábra) [10]. 


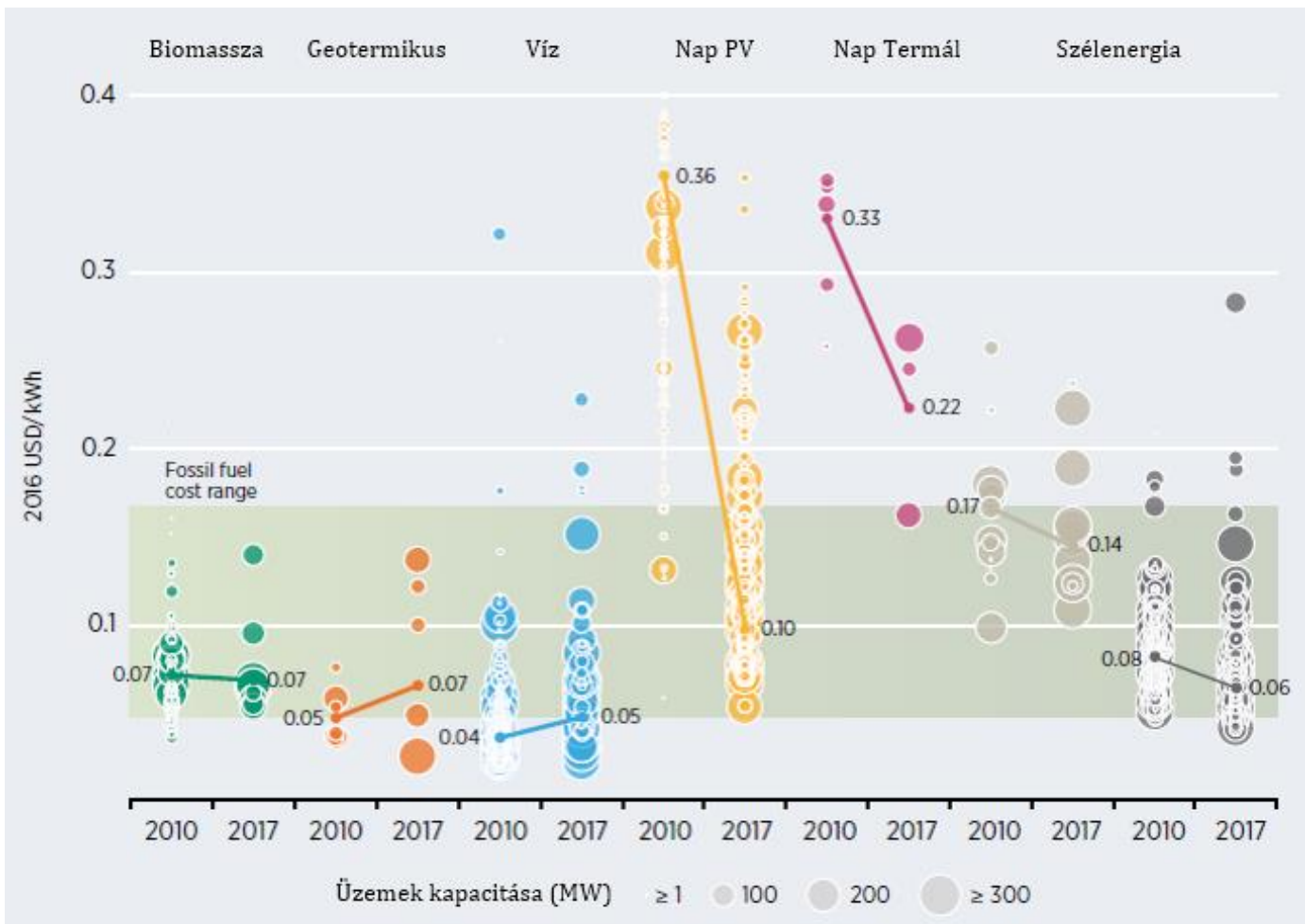

6. ábra: Az egyes megújuló energiaforrások villamos energiatermelési és beruházási költségei az LCOE (Levelized Cost of Electricity) értékek alapján a világban 2010 és 2017-ben

Forrás: IRENA Renewable Cost Database [10].

A körök átméróje az üzemek kapacitását, a középen található pontok értéke az LCOE képlet alapján számolt KWhkénti fajlagos elóállitási költségek átlagát jelzik. A sötétebb sáv a fosszilis energiát használó üzemek globális átlagos LCOE adatait mutatják.

A közvetlen összehasonlítás azonban igen nehéz, ha a fosszilis tüzelőanyagok környezeti kárait, az árváltozás kockázatát, a korábban kifizetett támogatásokat és a társadalmi költségeket is figyelembe vesszük. Az energiaárak alacsony szinten tartása mellett fontos az energiafelhasználás környezeti hatásának csökkentése [11]. Az utóbbi évtizedekben az emberi tevékenységből származó és fosszilis energia használatát kísérő $\mathrm{CO}_{2}$ és üvegházhatást okozó gázok (metán, nitrogén-oxidok, fluortartalmú gázok stb.) kibocsátása egyre erőteljesebben jelentkezik a légkör $\mathrm{CO}_{2}$ koncentrációjának növekedésében és jól érezhető a klímában jelentkező változások környezeti hatásában. A jelenlegi negatív irány folytatásával tovább növekedhet az átlagos felszíni hőmérséklet, amely már drámai változásokat eredményezhet az éghajlatunkban, a jelenlegi mezőgazdasági területek további csökkenése és a termesztési rendszerek átrendeződése terén [12]. Az energiából származó globális évi $\mathrm{CO}_{2}$-kibocsátás az 1980-as évektől kezdve fokozatosan emelkedett, az utóbbi években elérte az eddigi maximumot, évi mintegy 32 milliárd tonnát (GT). 2016-ban a levegő átlagos $\mathrm{CO}_{2}$ koncentrációja (403 ppm) 40\%-al magasabb volt, mint az 1800-as évek közepén, átlagosan 2 ppm/évi növekedés üteme volt tapasztalható az utóbbi évtizedben. Az emberi tevékenységből származó $\mathrm{CO}_{2}$ kibocsátás kb. 68\%-a az energia szektorhoz köthető. 2015-ben leginkább a villamos áram és hőenergia termelésből (42\%), a közlekedési (24\%) és az ipari szektorból (19\%) származott a $\mathrm{CO}_{2}$ kibocsátás nagy része [13]. A zöldenergia-források felhasználásával jelentősen csökkenthető lenne a $\mathrm{CO}_{2}$ kibocsátás mértéke, 
mindezek elősegítésére az utóbbi évtizedekben számos politikai célkitűzés, előírás és irányelv született.

\subsection{A megújuló energiaforrásokkal szembeni előírások és irányelvek a világon és az Európai Unióban}

2016-ban szinte a világ összes országának a politikai céljai között szerepelt a megújuló energiát célzó technológiák elősegítése, mintegy 176 országban létezik megújuló energiafelhasználást célzó irányelv [6]. Az Európai Unió 2020-ig tartó energia- és éghajlat politikai célkitűzéseinek keretében a 2009/28/EK irányelv előírja a megújuló energiaforrások megoszlását a végső energiafogyasztásból. EU-s szinten kötelező érvényű 20\%-os részarány eléréséhez az egyes tagországoknak eltérő részesedéssel kell hozzájárulniuk. A megújulók részarányának a közlekedésben minden tagállamnak egységesen, 10\%-os megoszlást kell elérniük [14].

Az Európai Bizottság 2014. január 22-én közzétette a 2020 utáni célkitűzésekről és politikákról szóló eszmecseréket elindító „Az éghajlat- és energiapolitika 2030-ra szóló kerete” (COM(2013) 0169) című zöld könyvet, amely a belső energiapiac megvalósítása, a külső energiaügyi kapcsolatok megerősítése, az energiaellátás biztonságának és energiahatékonyságának javítása, az EU saját energiaforrásainak leghatékonyabb felhasználását tűzte ki célul a megújuló energiaforrások jelentős szerepét hangsúlyozva [15].

A „Nemzeti Energiastratégia 2030” c. kiadványában számolt be a magyar kormány 2030-ig terjedő energiastratégiájáról. Az ún. „Atom-Szén-Zöld forgatókönyv” alkalmazásával célul tűzte ki az energiatakarékosságot, az energiafüggőség csökkentését, a megújuló energiaforrások lehető legnagyobb arányban történő felhasználását, a biztonságos atomenergia és ezen épülő közlekedés villamosítását. Nem mond le azonban a fosszilis üzemanyagok (földgáz, szén) stratégiai szerepéről sem. Magyarország földrajzi adottságait figyelembe véve leginkább a biomassza alapú - főleg erdészeti és mezőgazdaságból származó -, a geotermikus-, termál- és napenergia termelést tartja a kormány perspektivikusnak. Számítások szerint Magyarországon a rendelkezésre álló potenciális megújuló energia 2600-2700 PJ évente (1000-1100 PJ közötti az energiafelhasználás), amelyből a napenergia potenciálisan 70\%-os, szélenergia 20\%-os, a biomassza 7,5-12\%-os arányban részesülhet. A jövőben ezeken kívül még a geotermikus- és vízenergia jöhet számításba. Az EU 2020-ig, megújuló energiaforrások felhasználásáról szóló irányelv alapján Magyarországnak 13\%-ot kell elérnie a végső energiafogyasztásban. Ugyanakkor „Magyarország megújuló energia hasznosítási cselekvési terve”, a 2020-ig terjedő megújuló energiahordozó felhasználás alakulásáról c. kiadványában az olvasható, hogy a magyar kormány ennél magasabb, 14,65\%-os részesedést vállalt [16].

2008-tól kezdődően az EU országaiban fokozatosan nőtt a megújuló energiaforrások részesedése, 2016-ban a bruttó végső energiafogyasztásból elérte a 17\%-ot. Az egyes piaci szektorok energiafelhasználását nézve elmondható, hogy 2016-ban a megújulók részesedése a fútési és hűtési szektorban elérte a 19,1\%-ot, a villamos-áram termelésben a 29,6\%-ot és a közlekedésben a 7,1\%-ot (7a. ábra) [17]. Magyarország az előírt értéket már teljesítette, 2016-ban a részesedési arány 14,4\% 
volt. Hazánkban a megújulók felhasználása a villamos energiatermelésben 7,2\%-ot, a fütési és hütési energiaszektorban 20,8\%-ot, a közlekedésben 7,4\%-ot képviseltek (7b ábra) [18].

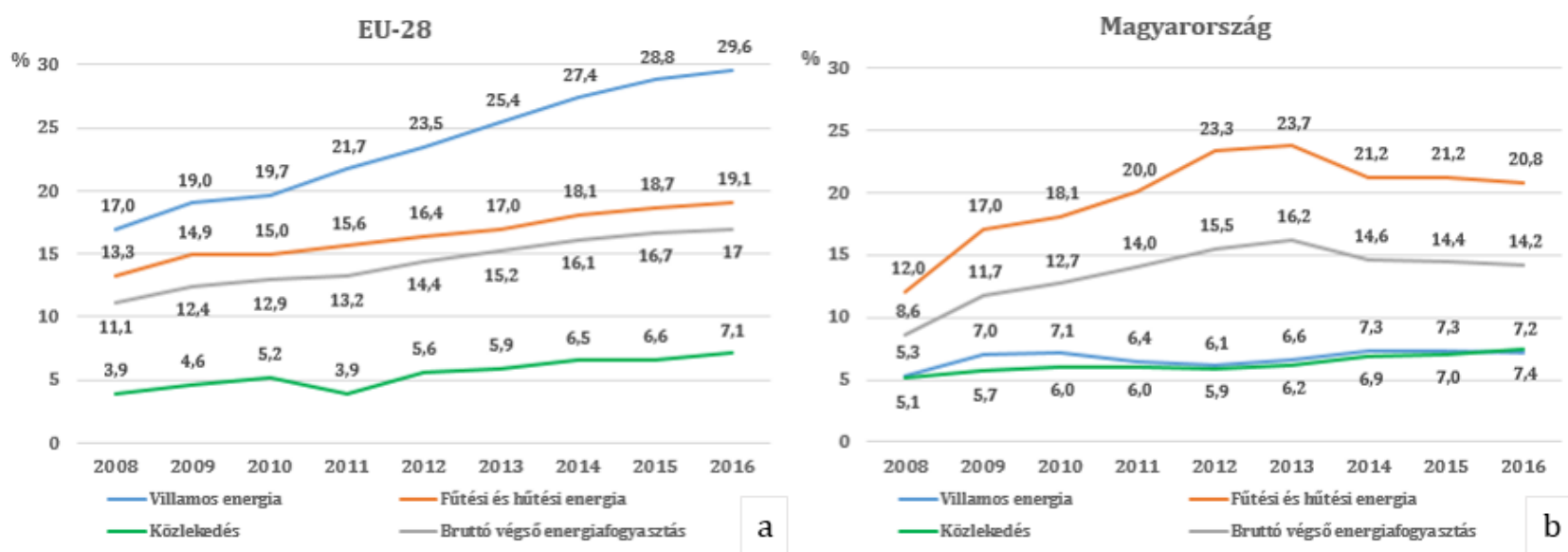

7. ábra: A megújuló energiaforrások megoszlásának alakulása a végső energia fogyasztásban a különböző szektorok esetén az EU-ban és Magyarországon 2008-2016 között

Forrás: saját szerkesztés, a) EUROSTAT és b) Magyar Energetikai és Közmü-szabályozási Hivatal (MEKH) adatai alapján $[17,18]$.

Az EU 2020-ig tartó irányelvei között található még az üvegházhatást okozó gázok kibocsátásának, az 1990-es évek szintjéhez képest legalább 20\%-al való csökkenésének elérése. Az ENSZ 21. klímacsúcsán számos ország kötelezte el magát az éghajlatváltozás megelőzése és az emberi civilizáció védelme érdekében. 2015. december 12-én elfogadott párizsi megállapodás célként fogalmazza meg a 1,5 ${ }^{\circ} \mathrm{C}$-os globális felmelegedési küszöbértéket 2030-ra. A megállapodás elköteleződést jelent a fosszilis energiahordozók arányának mérséklésére, a szén-dioxid-kibocsátás csökkentésére és a globális felmelegedés legfeljebb $2^{\circ} \mathrm{C}$, de lehetőség szerint $1,5^{\circ} \mathrm{C}$ alatt tartására. 2016-ban több, mint 100 ország írta alá a hivatalos csatlakozást a párizsi egyezményhez [19]. A jelenlegi tendenciák megváltoztatásához azonban ez nem elégséges, mert a $\mathrm{CO}_{2}$ fokozott megkötésére is szükség van. Ennek megvalósítása - a mai technológiai tudás szintjén - leginkább a növények fotoszintézisén keresztül valósítható meg. Ezzel párhuzamosan azonban fontos kérdés az is, hogy az egyre szűkösebben rendelkezésre álló termőföldön az élelmiszertermelés mellett milyen mértékben történjen a bioenergia termelése.

\section{Bioökonómiai kutatások jelentősége a növényi biomassza hatékonyabb hasznosításában}

\subsection{Bioökonómia jelentősége}

A bioökonómia területe kiterjed az élelmiszer-termelésre, a mezőgazdaság eredetű nem élelmiszer célra termesztett termékek és a bioenergia előállításának területére, azok gazdasági, szociális és környezetvédelmi szempontok szerinti tanulmányozásra. A bioökonómiai a megújuló energiaforrások hatékonyabb felhasználására fokuszálva tartja szem előtt az üvegházhatást okozó gázok 
kibocsátásának csökkentését, a fosszilis energiafüggőség mérséklését, a természeti erőforrások fenntartható hasznosítását és az élelmiszerbiztonság növelését [20, 21]. A Gazdasági Együttműködési és Fejlesztési Szervezet - OECD, The Bioeconomy to 2030: Designing a Policy Agenda c. kiadványa hívta fel a figyelmet a biológia, különösen a biotechnológia fejlődésével kialakult új terület, a bioökonómia jelentőségére [22]. 2012-ben az Európai Bizottság Innovating for Sustainable Growth: A Bioeconomy for Europe c. kiadott közleményét követően [23], számos EU tagország, többek között Németország, az USA és más országok nemzeti stratégiái között is megjelent a bioökonómia kifejezése [24]. 2012-ben Európában a bioökonómia 2 ezermilliárd eurós piaca, amely magába foglalja a mezőgazdaság, erdészet, élelmiszer, kémiai vegyületek és bioenergia területét már 22 millió munkahelyet teremtett [23]. A nemzetközi és hazai tanulmányok tucatjai a megújuló energiaforrások alkalmazása területén, fenntartható megoldások sorában említik a biomassza különböző célú hasznosítását is.

\subsection{Biomassza hasznosítás helyzete a világban}

A bioenergia, legyen szó tradicionális vagy modern biomasszák hasznosításáról, a legnagyobb arányban járulnak hozzá a globális megújuló energiaellátáshoz. 2016-ban a biomasszából a primer előállítás megközelítőleg már 62,5 EJ energiával részesedett, 2010-hez képest ez átlagosan évi 2,5\%-os növekedést jelent. Az erdészet 87\%-ban, az emberi tevékenységből származó ipari és kommunális hulladékok hasznosítása 3\%-ban, a mezőgazdasági szektor 10\%-ban járult hozzá az energiaellátáshoz, amelyből a bioetanol (4\%), a biodízel $(2,4 \%)$ és a biogáz előálítás $(2,6 \%)$ jelentősége egyaránt növekedett (8a. ábra). 2015-ben a tradicionális biomasszának leginkább az épületek hőenergiával való ellátásában volt jelentősége (20,5\%). Az épületek üzemeltetéséhez szükséges hőenergia 2,8\%-át, az ipar által felhasznált hőenergia 7,3\%-át adták a modern biomasszák, a közlekedésben 2,6\%-ot és a villamos áram termelésben 2,4\%-ot tettek ki (8b. ábra) [6].
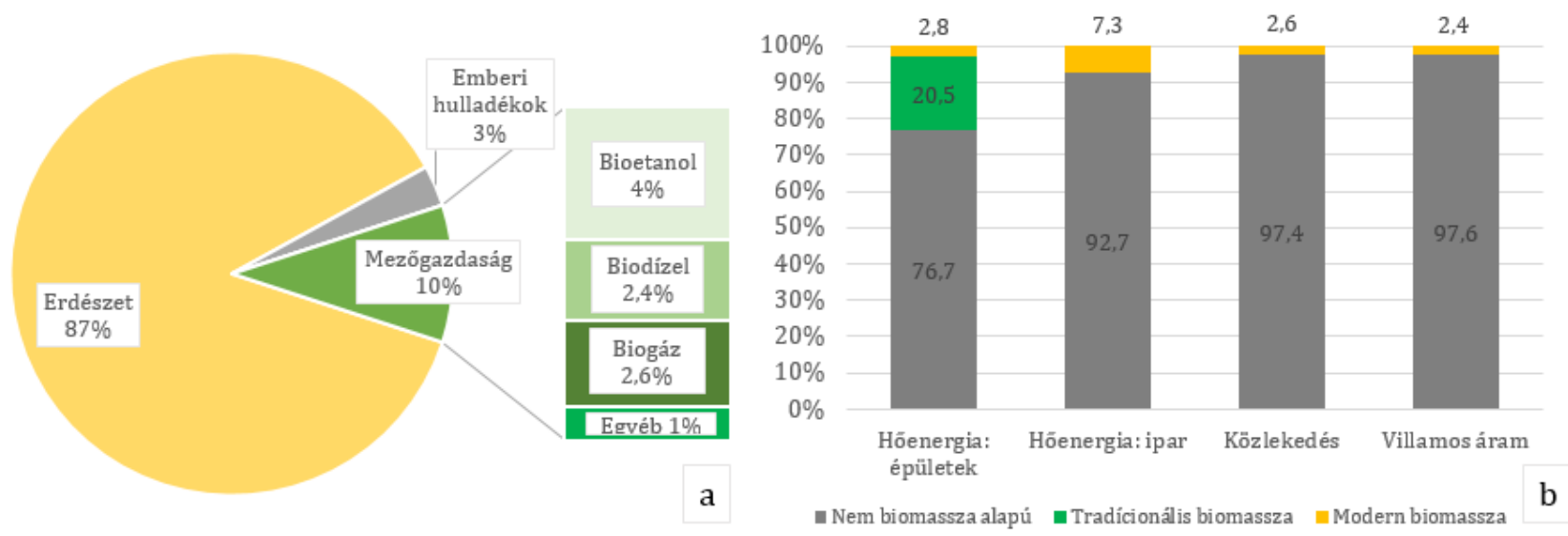

8. ábra: A biomassza alapú energiaforrások származása és részesedése globális szinten az egyes szektorokban 2015-ben. Forrás: saját szerkesztés, Renewable Energy Policy Network for the 21st Century adatai alapján [6].

A világon a rendelkezésre álló növényi biomassza igen sokrétű, különböző módon előkészíthetőek, feldolgozhatóak. A magas cukor-, keményítő- és olajtartalmú növényeken felül ma már kifejezetten bioipari hasznosításra alkalmas fás- és lágyszárú energianövényeket, algákat és melléktermékeket is 
hasznosítanak (erdészeti, mezőgazdasági, kommunális és ipari hulladékok). Jelenleg a „zöld kémia” iparágon belül (a kőolaj-alapú, vegyipari szintetikus alapanyagok kiváltása növényi, biomassza eredetű anyagokkal) az eltüzelés, a pirolizálás, a biogáz-, a bioetanol- és a biodízel előállítás területeinek van jelentősége. De a növényi biomassza ma már nem csak energetikai célokra, hanem különböző kémiai alapvegyületek előállítására is alkalmas (9. ábra) [25].

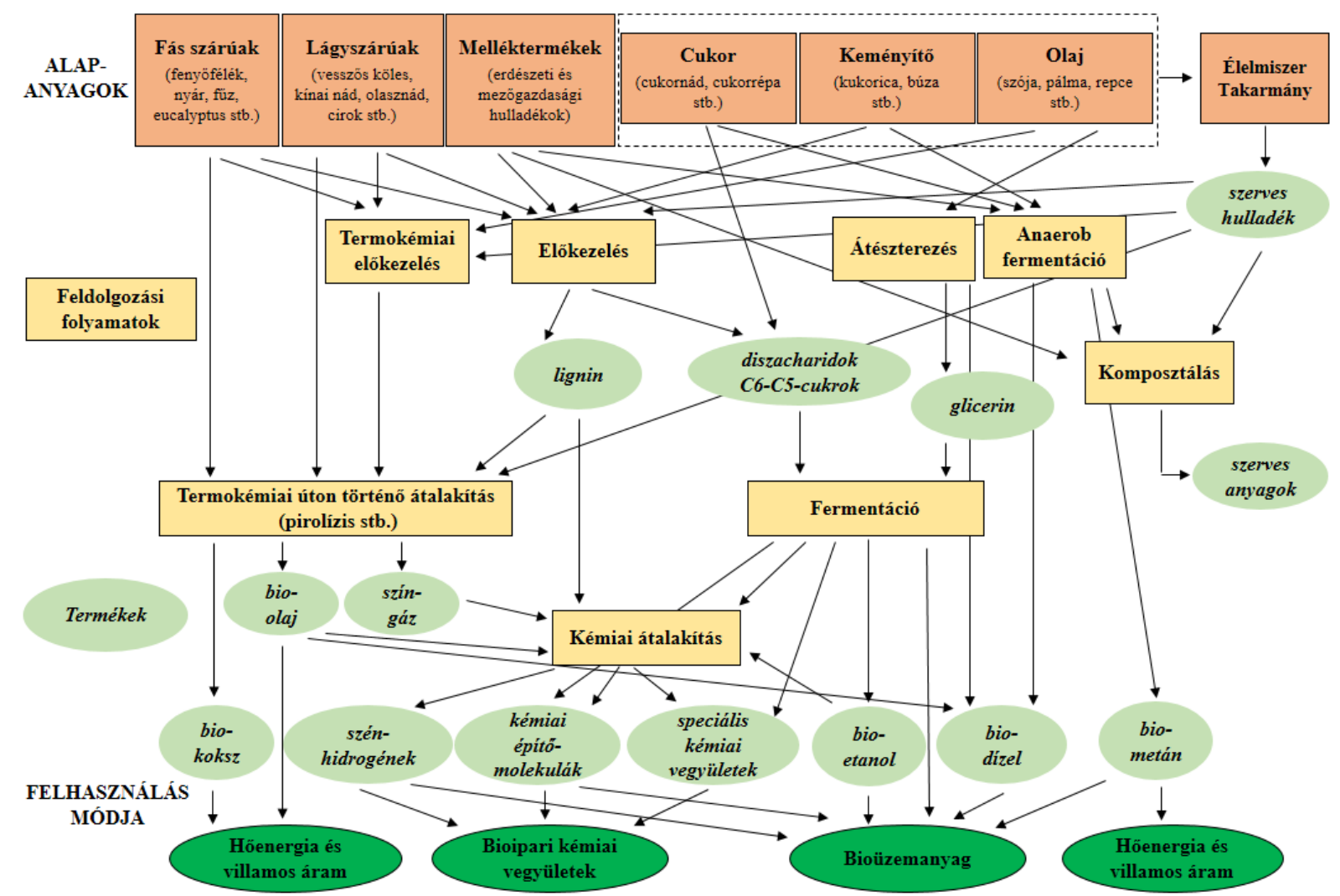

9. ábra: A különböző növényi alapanyagokból előállítható termékek, azok feldolgozási folyamatai és hasznosítási lehetöségei

Forrás: saját szerkesztés, STICHNOTHE et al. alapján [25].

Megjegyzés: A sötét szürke téglalapok az egyes feldolgozási folyamatokat, a világos szürke ellipszisek az elóállított köztes- és végtermékeket jelölik.

A „zöld kémia” ipar még számos esetben csak kísérleti szinten működik. A nem élelmiszer vagy takarmány eredetű cukrokból és keményítőből nélkülözhetetlen kémiai építőkockákat, pl. a politejsavat (PLA), szubproduktumokat, nagyobb hozzáadott értékű végtermékeket lehet előállítani a felhasználó iparok számára [12]. A bioalapú kémiai ipar fő termékei jelenleg a nem élelmezési célú keményítő, a cellulóz-rost, az egyéb cellulóz-származék, a növényi olajok, a zsírsavak, a bioüzemanyagok, a citromsav, a műanyagipar különböző alapvegyületei stb. [25]. Napjainkig az alacsony fosszilis energiahordozó árak mellett a bioalapú kémiai ipar és polimer-gyártás még számos problémával küzd [26], de a biológiai úton lebomló bioalapú műanyagipar piaca várhatóan emelkedni fog 2020-ra [25]. 
A bioüzemanyag előállítás szempontjából a biomassza-alapanyagok széles köre áll rendelkezésre, de ma még leginkább a bioetanol előállításhoz használt nagy keményítő- és cukortartalmú mezőgazdasági növényeket (elsősorban kukorica, cukornád) és a biodízelgyártásban használt olajnövényeket (elsősorban szója, repce) használnak fel. Egyre inkább emelkedik a cellulóz-tartalmú mezőgazdasági és erdészeti melléktermékekből, hulladékokból, kifejezetten erre a célra termesztett fás- és lágyszárú energianövényekből és algából előállított bioüzemanyagok aránya is [27, 28]. A bioüzemanyagok használata jelenleg 3-4\%-ot képvisel a közlekedésben, amely a globálisan előállított bioenergia 7\%-át jelenti. A bioüzemanyagok alacsony, de fokozatosan növekvő részesedését mutatja, hogy az előállításának volumene a 2000-es 18 milliárd liter termelési szintről 2013-ra 118 milliárd literre emelkedett globális szinten. 2015-ben 147 milliárd liter folyékony bioüzemanyagot állítottak elő a világon, amelyet főleg a bioetanol (116 milliárd liter), a biodízel (30,1 milliárd liter), a hidrogenizált növényi olajok és cellulóz alapú bioüzemanyagok tették ki [29].

Mivel ma még a bioüzemanyagok előállításához leginkább élelmiszernövényeket (első generációs növények) használnak fel, így kiéleződött a verseny a korlátozott mértékben rendelkezésre álló termőföldért. Jelenleg megközelítőleg 40 millió hektár, a globális szántóterületek 2,5\%-a a bioüzemanyag-gyártás területe. Az első generációs növények bioüzemanyag előállításakor keletkezett melléktermékeket (évente 60-70 millió tonna termelődik) elsősorban takarmányozási célból, energiaés tápanyagforrásként hasznosítják, csökkentve a földhasználat mértékét 1,5\%-ra (pl.: szárított gabonatönköly (Distiller's dried grains with solubles - DDGS), a kukorica glutén takarmány (Corn Gluten Feed - CGF), az olajpogácsa stb.) [30].

Az utóbbi időszakban a bioüzemanyag előállításra alkalmas üzemek száma folyamatosan nő, a második generációs, lignocellulóz alapú bioetanol előállítás részesedése is növekszik. Ezek az üzemek leginkább az USA-ban (POET DSM és DuPont cégek üzemei), Brazíliában (GranBio), Kanadában (Enerkem) és Európában (Göteborg Energi, Beta Renewables) találhatóak [28]. STICHNOTHE et al. [25] alapján a második generációs, nem élelmiszeripari növényeket felhasználó biofinomító üzemek termelési költségei ma még sokkal magasabbak, mert az alapanyagok előkezelésére van szükség, a cellulóz, a hemicellulóz és a lignin szétválasztására, amelyhez több energia és kémiai vegyület szükséges. A keletkezett melléktermékek hasznosítása még nem megoldott, ellentétben az első generációs bioüzemanyagok termelésekor keletkezett, a takarmányipar számára nélkülözhetetlen energia- és fehérjeforrásokkal szemben. A fermentációs folyamatokhoz szükséges hatékony cellulóz bontó enzimek költsége is még meghatározó, de az utóbbi időszakban a kutatás-fejlesztési munkáknak köszönhetően egyre inkább nem jelentenek nagy problémát [25].

A modern bioenergia-termelésben a bioüzemanyag-gyártás azért játszik fontos szerepet, mert a széndioxid kibocsátás jelentős hányada a közúti közlekedéshez használt üzemanyagokból származik. A bioüzemanyag felhasználással megtakarított üvegházhatású gázok mennyiségéről szóló tanulmányok nagy különbségeket mutatnak, de összességében pozitív hatásról számolnak be. Jelenleg a bioüzemanyagot tartalmazó üzemanyag-keverékek előállításnak van realitása, de a bioüzemanyaggyártás termelését számos tényező befolyásolja (olajár, technológiai fejlődés, energiahatékonyság, közlekedés modernizációja, társadalmi és környezeti hatások stb.) [31]. 
Hazánkban a „zöld kémia” ipar egyik megálmodója egy magyar gépészmérnök, a biotechnológia fogalom atyja Ereky Károly (1878-1952) volt. Számos globális stratégiai jelentőségű, élelmezéssel, mezőgazdasági termeléssel és biotechnológiával kapcsolatos projekt mellett a zöld növényi biomasszából nyerhető levélfehérje előállítási technológiák alapjainak kidolgozását végezte el Magyarországon 1926-1933 között [32]. A bioipari nyersanyagok hasznosításának területén a jövőben egy potenciális irány lehet még a növényi levélfehérje-koncentrátumok előállítása (Leaf Protein Concentrate - LPC). Jelenleg az egyik legjelentősebb fehérjeforrásból, a szójából 2015-ben globális szinten 320 millió tonnát termeltek, amely 85\%-át az USA, Brazília és Argentína állította elő. Ezekben az országokban a szójaterületek 90-98\%-án azonban géntechnológiával nemesítetett (GM) szójababot termesztenek. Az EU-ban és Magyarországon a biotechnológiai eredményeinek hasznosításával, a GMO-kal szembeni elutasítás következményeként megindult a GM szóját kiegészítő és helyettesítő megoldások kutatás-fejlesztése, az alternatív fehérjeforrások és nem géntechnológiai úton előállított termékek előállítása. A globális takarmány- és élelmiszerláncban a GM-szójatermények egyre növekvő volumene és az EU alacsony szója önellátottsága azt eredményezi, hogy a szójának egyelőre nincs sok alternatívája [33].

\subsection{Az új generációs bioipari növények hasznosításának perspektívái az olasznád példáján}

A biomassza célú növénytermesztés számos biológiai, ökológiai, gazdasági és technikai problémával küzd. A szántóföldi növénytermelés leginkább egyéves növényeken alapul, ami szakértők szerint nem csökkenti a $\mathrm{CO}_{2}$-szintet, mert az intenzív talajművelés több $\mathrm{CO}_{2}$-ot mobilizál, mint a biológiai megkötés. A növekvő élelmiszerszükséglet miatt sokat lehet változtatni a jelenleg termelt mezőgazdasági haszonnövények spektrumán. Azonban, ha évelő növényfajokkal valósítjuk meg a célzott biomasszatermelést, a földalatti részek jelentősen növelik a talaj szervesanyag-felhalmozását, ezáltal a szénmérleg jelentős egyensúlyát biztosítja [12].

A Debreceni Egyetemen, MÉK, Növény Biotechnológiai Tanszék korábbi és jelenlegi munkatársai több mint egy évtizede végeznek biológiai, genetikai, agronómiai és biotechnológia kutatásokat a marginális területeken is termeszthető, bioipari feldolgozásra alkalmas évelő, óriás termetű rizómás füfélékkel és mérsékelt égövi mályvafélékkel, ún. biogenerációs növényekkel. A kifejezés az utóbbi években merült fel több kezdeményezés hatására, amely a biotechnológiai módszerrel szaporítható, új generációs növényeket foglalja magában [12]. Az utóbbi években különböző, hatékony szaporítóanyag előállítási technológiák született a növényfajok esetén különböző kutatási programok keretein belül [34-36]. 


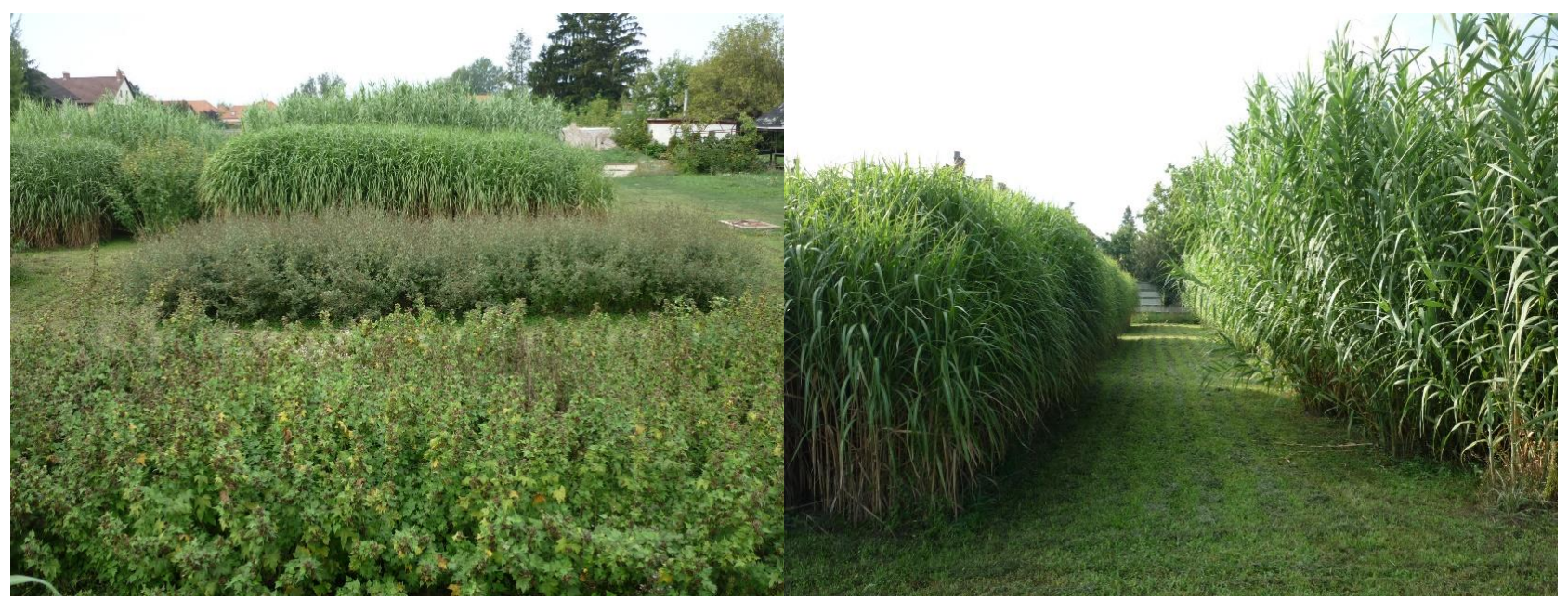

10. ábra: Új generációs, bioipari feldolgozásra alkalmas növények a Debreceni Egyetem, Biomassza Bemutató Kertjében (2016).

Forrás: saját fotók.

Az új generációs biomassza növényeket az intenzív és környezetkímélő biomassza-termelés céljából választjuk ki és nemesítjük tovább. Mivel elkerülhetetlen, hogy a biomassza-termelés marginális minőségű termőföldekre szoruljon vissza és ne versengjen az élelmiszertermeléssel, a szárazságtűrés vagy pont az ellenkezője az elárasztás, belvíztűrés fontos szempont lehet a kiválasztásban. Más szélsőséges termőhelyi viszonyoknak is ellenálló fajok termesztésével indokolttá válik a magas só, szélsőséges $\mathrm{pH}$, agrokémiai maradványok, nehézfém szennyeződésű és egyéb olyan területek hasznosítása, amelyeken az élelmiszernövények termelése nem lehetséges. A folyamatos fenntarthatóság szempontjából elsősorban évelő kultúrák jöhetnek számításba, mert az évenkénti talajművelés lerontja a $\mathrm{CO}_{2}$-megkötést, továbbá a nyugalmi periódus előtt a szárból részben, vagy egészben visszaszállítják a talajban az ásványi tápanyagokat, ezzel rehabilitálhatják a marginális minőségű termőföldet. Kifejezetten lignocellulóz alapanyagok előállítása céljából termesztett növények széles skálája áll rendelkezése a világban az általunk vizsgált növényfajokon kívül [12, 36].

A kutatásaink során vizsgált, egyik ilyen ígéretes biomassza növény az olasznád (Arundo donax L.), amely a múlt század végétől kezdve, mint bioenergetikai-, bioipari nyersanyag került az évelő, lágyszárú biomassza növénykutatások egyik fókuszába. A növény iránti érdeklődést a magas hektáronkénti biomassza hozamának (klímától és talajtól függően 20-40 száraz tonna/ha), kedvező kémiai összetételének, alacsony inputköltségeinek és sokoldalú hasznosítási lehetőségeinek köszönheti. A világon a termesztése elsősorban bioenergia, biogáz és bioüzemanyag előállítási célokat szolgál [37, 38]. Az olasznád képes alkalmazkodni különböző talajtípusokhoz, marginális területen, időszakosan elöntött vagy éppen sós területeken is képes megélni [39]. Számos tudományos publikáció számol be a növény nehézfémekkel, szennyezőanyagokkal és különböző szelénformákkal szembeni toleranciájáról [40-43] és sótűréséről [44-45]. A második világháborút megelőzően az olasznád, mint potenciális cellulóz és műselyem alapanyag volt Olaszországban jelentős. A Torviscosa néven alapított első olasz „technopolis” létesítésének fő célja az olasznád feldolgozásán alapuló, iparszerű cellulóz előállítás volt, egyrészt a viszkóz műselyem elóállítás, másrészt papír- és lőporgyártás céljából [46]. Az olasznád elfásodott szárát fa- vagy rézfúvós hangszerek fúvókájaként is 
használják [47] A növény, mint mezőgazdasági eredetű, fenntartható zöld építőanyag is használható [48].

Az olasznád hektáronkénti biomasszájának és más energia növényekhez hasonló fütőértékének (pl.: nyárfa, kínai nád, vesszős köles) köszönhetően az egyik potenciális felhasználási lehetősége a közvetlenül tüzelésből származó energia-elóállítás. A növényből mért fútőérték 17-20 MJ/kg között van, de egy másik évelő lágyszárú energianövényhez, a vesszős köleshez hasonlóan magas hamu- és szilícium tartalommal rendelkezik [38]. A növény szilícium-tartalma a magas kálium- és klórtartalommal párosulva problémát jelenthet korróziós szempontból, elégetésekor káros vegyületek (nitrogén-oxidok, hidrogén-klorid, kén-dioxid és szén-monoxid) is keletkezhetnek [49]. Különböző agronómiai, környezetvédelmi és gazdasági szempontok alapján hasonlították össze az olasznád termesztésének és feldolgozásának hatékonyságát a kínai nád, a gyorsvágású nyár és más egyéves potenciális energiatermelésre alkalmas növényeket (cukorrépa, durum búza, cirok, napraforgó) értékeivel. Az évenkénti nettó energiahozam az olasznád esetében a legnagyobb ( $\sim 600 \mathrm{GJ} / \mathrm{ha})$, sorrendben a kínai nád $(\sim 450 \mathrm{GJ} / \mathrm{ha})$, a nyár ( $300 \mathrm{GJ} / \mathrm{ha})$ és az egyéves növényfajok $(\sim 110 \mathrm{GJ} / \mathrm{ha})$ követik. Az évenkénti ÜHG kibocsátás tekintetében az egyéves fajok termesztésekor hektáronként $1400 \mathrm{~kg}$, a kínai nád és olasznád esetében közel azonos $800 \mathrm{~kg}$, a nyárfa esetében $460 \mathrm{~kg} \mathrm{CO}_{2}$ egyenértékű kibocsátással lehet számolni [50-53].

Az olasznádból száraz-anyagra vetítve kevesebb biogázt lehet előálítani, mint más hagyományos energianövényekből (kukorica, cirok, tritikálé stb.). Ennek ellenére a hektáronkénti magas biomassza hozamának köszönhetően fajlagos biometán termelése magasabb, mint más energianövényeké. Biomassza hozamtól függően átlagosan $9200 \mathrm{Nm}^{3} \mathrm{CH}_{4}$ állítható elő a növényből hektáronként (7170$11280 \mathrm{Nm}^{3} \mathrm{CH}_{4}$ ) évi egyszeri betakarítás esetén [54]. Az Arundo Italia Ltd. (Olaszország) kalkulációi alapján az olasznádból tonnánként akár $160 \mathrm{~m}^{3}$, a kukoricából tonnánként $220 \mathrm{~m}^{3}$ biogáz állítható elő. 15 éves termesztési ciklus esetén hektáronként harmad annyi (11850 euro/ha és 40727 euro/ha sorrendben) költséggel lehet számolni [55-56]. A probléma a biogáz előállítása során a volatilis (lebegő) anyagok jelenléte lehet (szilícium tartalmú vegyületek), amelyek az alapanyag emésztése során szilíciummá alakulhat át [49, 50].

Az olasznád, mint lignocellulóz alapanyag a második generációs bioetanol előállítás potenciális nyersanyaga lehet. Williams et al. [44] és Jaradat [57] beszámolt hektáronkénti 11000 liter bioetanol előállításáról (45 száraz tonna biomassza hozam esetén). Corno et al. [38] 12 690-15 228 liter/ha bioetanol előállításról számolt be, így az olasznádból előállítható magas fajlagos etanol hozam átlagosan 20, akár 50\%-al is meghaladja más bioetanol előállításra alkalmas növények etanol kihozatalát. 2013-ban a Mossi \& Ghisolfi Group, Észak-Olaszországban (Crescentino) létesített második generációs 60 ezer tonna/év kapacitású demonstrációs cellulóz-etanol üzeme alapanyagként mezőgazdasági melléktermékeket, kínai nádat, vesszős kölest, cirkot és olasznádat használ fel. Gazdaságossági kalkulációik alapján az olasznádból és a búza szalmájából történő bioetanol előállítás évenkénti teljes költsége tonnánként 500 euro alatt van, míg a ciroké 600 euro körül alakul, 100000 tonna/év kapacitás mellett. Leginkább perspektivikus alapanyagnak a búzaszalmán kívül az olasznádat tekintették 5 tonna hektáronkénti etanol kihozatalának köszönhetően, amely évi 20 száraz tonna/ha átlagos biomassza hozammal értek el. Megállapították, hogy az olasznádból történő 
bioetanol használatával csökkenthető leginkább az üvegházhatást okozó gázok kibocsátása a vizsgált növényfajok esetén. Számításaik alapján az olasznád bioüzemanyagként történő hasznosításával hektáronként átlagosan évi 8 tonna ÜHG-kibocsátás csökkentése érhető el [58].

\section{Következtetések és javaslatok}

A megújuló energiaforrások és a fosszilis energiahordozók között kialakult verseny mellett számos potenciális biomassza növény versenyez ma már a korlátozott mennyiségben rendelkezésre álló termőföldért. A biomassza növények széles spektruma áll rendelkezésre, de a hivatalosan, az egyes bioipari célokra javasolt fajok-fajták száma kevés, és nem lehet kisszámú termelési adatok és nem megfelelő feldolgozóipar nélkül telepíteni és beruházni. Mivel a modern megújuló energiaforrások (elsősorban a nap és a szél) nem kerül pénzbe, ezért leginkább ezen energiaformák elóállításának a beruházása dominált az utóbbi 10 évben. Ehhez hozzájárul a technológiai fejlődése, amellyel ma már a napenergia hasznosítása is egyre inkább versenyképessé válik a víz-, a szélenergia és a biomassza mellett. A biomassza alapú termelésben a jövőben termesztendő növényfajokat nem lehet csak úgy begyűjteni, azok hasznosítását tudományos alapossággal meg kell tervezni, azért, hogy a mezőgazdaság ezen új iparága, az új kémiai nehézipar is felvegye a versenyt a fosszilis vagy más energiaforrásokkal szemben bizonyos területeken. Fontos, hogy az „egyetlen jó út van” típusú szemlélet nem követhető, továbbá a modern megújuló energiaforrások gyorsütemű terjedése nagyban befolyásolja a biomassza alapú ipar további fejlődését, amelyet a fosszilis energiahordozók domináns szerepe az elkövetkező évtizedekben még nagymértékben meg fogja határozni.

\section{Köszönetnyilvánítás}

AZ EMBERI ERŐFORRÁSOK MINISZTÉRIUMA ÚNKP-17-3. KÓDSZÁMÚ Új NEMZETI KivÁLÓSÁG PROGRAMJÁNAK TÁMOGATÁSÁVAL KÉSZÜLT.

\section{Hivatkozások}

[1] IEA (2017) Key world energy statistics. International Energy Agency, https://www.iea.org/publications/freepublications/publication/KeyWorld2017.pdf, 97 p.

[2] IEA (2018a) World: Balances for 2000 in thousand tonnes of oil equivalent (ktoe) on a net calorific value basis. International Energy Agency Online Statistics Database, http://www.iea.org/statistics/statisticssearch/report/?country=WORLD\&product=Balances\& year $=2000$

[3] IEA (2018b) World: Balances for 2015 in thousand tonnes of oil equivalent (ktoe) on a net calorific value basis. International Energy Agency Online Statistic Database, http://www.iea.org/statistics/statisticssearch/report/?country=WORLD\&product=Balances\& year $=2015$

[4] WBA (2017) WBA Global Bioenergy Statistics 2017. World Bioenergy Association, http://worldbioenergy.org/uploads/WBA\%20GBS\%202017_hq.pdf, 80 p. 
[5] EEA (2017) Renewable energy in Europe - 2017 Update, Recent growth and knock-on effects, European Environment Agency, https://www.eea.europa.eu/publications/renewable-energyin-europe. $74 \mathrm{p}$.

[6] REN21 (2017) Renewables 2017, Global Status Report. Renewable Energy Policy Network for the 21st Century, http://www.ren21.net/wp-content/uploads/2017/06/178399_GSR_2017_Full_Report_0621_Opt.pdf, 302 p.

[7] European Commission (2017) EU energy in figures, Statistical Pocketbook 2017. https://ec.europa.eu/energy/sites/ener/files/documents/pocketbook_energy_2017_web.pdf. $265 \mathrm{p}$.

[8] KSH (2018a) Primer energiamérleg (1990-) [petajoule]. Központi Statisztikai Hivatal, https://www.ksh.hu/docs/hun/xstadat/xstadat_eves/i_qe001.html

[9] KSH (2018b) Végső energiahordozó felhasználás (1995-) [ezer toe]. Központi Statisztikai Hivatal, https://www.ksh.hu/docs/hun/xstadat/xstadat_eves/i_ui009.html

[10] IRENA (2018) Renewable Power Generation Costs in 2017. International Renewable Energy Agency, $\quad$ https://www.irena.org/-/media/Files/IRENA/Agency/Publication/ 2018/Jan/IRENA_2017_Power_Costs_2018.pdf, 160 p.

[11] J. Popp J. - N. Potori (szerk.). (2011) A biomassza energetikai célú termelése Magyarországon. Agrárgazdasági Kutató Intézet, Budapest. ISBN 978963491570 6, 160 p.

[12] M. G. Fári - G. Antal - E. Kurucz - É. Domokosné Szabolcsy (2014) Biogenerációs növények kutatása a Debreceni Egyetemen és a magyar agrár-biotechnológiai innováció néhány kitörési pontja. In: Fenntartható energetika megújuló energiaforrások optimalizált integrálásával (DEnzero). Akadémiai Kiadó, ISBN: 978963059540 7, 7. fejezet, pp. 237-268.

[13] IEA (2017) World energy balances 2017. International Energy Agency, https://www.iea.org/statistics/relateddatabases/worldenergybalances/, $747 \mathrm{p}$.

[14] European Parliament (2009) Directive 2009/28/EC of the European Parliament and of the Council of 23 April 2009 on the promotion of the use of energy from renewable sources and amending and subsequently repealing Directives 2001/77/EC and 2003/30/EC.

[15] European Commission (2014) Az éghajlat- és energiapolitika 2030-ig szóló keret javaslat. Európai Bizottság, http://www.consilium.europa.eu/hu/policies/climate-change/2030climate-and-energy-framework/

[16] Nemzeti Fejlesztési Minisztérium (2012) Nemzeti Energiastratégia 2030. Magyarország. ISBN 978-963-89328-1-5, 136 p.

[17] EUROSTAT (2018) Share of renewable energy in gross final energy consumption. European Commission, http://ec.europa.eu/eurostat/web/products-datasets/-/t2020_31\&lang=en

[18] MEKH (2018) Megújuló energiaforrások felhasználásának részaránya 2005-2016. Magyar Energetikai és Közmü-szabályozási Hivatal, http://www.mekh.hu/download/d/ ef/40000/6_1_megujulo_energiaforrasok_felhasznalasanak_reszaranya_2005_2016.xlsx

[19] COP23 (2017) Overview of the work of the Conference of the Parties and the subsidiary and constituted bodies on the work programme under the Paris Agreement. United Nations Climate Change, http://unfccc.int/2860.php

[20] R. M'Barek - G. Philippidis - C. Suta - C. Vinyes - A. Caivano - E. Ferrari - T. Ronzon - A. S. Lopez - F. Santini (2014) Observing and analysing the Bioeconomy in the EU-Adapting data and tools to new questions and challenges. Bio-based and Applied Economics 3 (1) pp. 83-91, doi: 10.13128/BAE-14189 
[21] J. R. Hess - P. Lamers - H. Stichnothe - M. Beermann - G. Jungmeier (2016): Bioeconomy strategies. In:P. Lamers - E. Searcy - J. R. Hess - H. Stichnothe (Eds.).: Developing the Global Bioeconomy: Technical, Market, and Environmental Lessons from Bioenergy. Stichnothe Academic Press, Elsevier. ISBN: 978-0-12-805165-8., pp. 1-11.

[22] OECD (2009) The Bioeconomy to 2030: Designing a Policy Agenda, Main Findings. Organisation for Economic Cooperation and Development (OECD) Paris, France, pp. 35-38.

[23] European Commission (2012) Innovating for Sustainable Growth: A Bioeconomy for Europe. COM (2012) final. European Commission (EC), Brussels, Belgium

[24] K. McCormick - N Kautto (2013) The bioeconomy in Europe: An overview. Sustainability, 5 (6) pp. 2589-2608. doi:10.3390/su5062589

[25] H. Stichnothe - H. Stroz - D. Meier - I. de Bari - S. Thomas S. (2016): Development of secondgeneration biorefineries. In: P. Lamers - E. Searcy - J. R. Hess - H. Stichnothe (Eds.).: Developing the Global Bioeconomy: Technical, Market, and Environmental Lessons from Bioenergy Academic Press, Elsevier. ISBN: 978-0-12-805165-8., pp. 11-40.

[26] R. Mülhaupt (2013) Green polymer chemistry and bio-based plastics: dreams and reality. Macromolecular Chemistry and Physics, 214 (2) pp. 159-174. doi:10.1002 /macp.201200439

[27] J. Popp - Z. Lakner - M. Harangi-Rákos - M. Fári (2014) The effect of bioenergy expansion: food, energy, and environment. Renewable and Sustainable Energy Reviews, 32, pp. 559-578. http://dx.doi.org/10.1016/j.rser.2014.01.056

[28] J. Popp - M. Harangi-Rákos - Z. Gabnai - P. Balogh - G. Antal - A. Bai (2016) Biofuels and their co-products as livestock feed: Global economic and environmental implications. Molecules, 21 (3) 285. doi:10.3390/molecules21030285

[29] J. Oláh -P. Lengyel - P. Balogh - M. Harangi-Rákos - J. Popp (2017) The role of biofuels in food commodity prices volatility and land use. Journal of Competitiveness, 9 (4) pp. 81-93.

[30] J. Oláh - P. Lengyel -P. Balogh - A. Nagy - J. Popp (2017) Biofuels co-products as livestock feed: animal feed market and land use implications. Selye E-Studies 8 (2) pp. 17-31.

[31] J. Popp - S. Kot - Z. Lakner - J. Oláh (2018) Biofuel use: peculiarities and implications. Journal of Security and Sustainability Issues, 7 (3) pp. 477-493. https://doi.org/10.9770/jssi.2018.7.3(9)

[32] K. Ereky (1925) A zöldtakarmánymalom és a nagy istállóüzemek. Athenaeum Irodalmi és Nyomdai Részvény-Társulat, Budapest, 83 p.

[33] M. G. Fári - J. Popp (szerk.), M. Molnár - M. G. Fári - G. Antal- É. Domokosné Szabolcsy- M. Harangi-Rákos - E. Kurucz - U. P. Kralovánszky - Zs. Lisztes-Szabó- K. Pető - Z. Szakály - Sz. Veres - J. Popp (2016) BIOTECHNOLÓGIA-ANNO 1920-1938, Ereky Károly programja a fehérjeprobléma megoldásáról és napjaink feladatai. 436 p. Szaktudás Kiadó Ház, ISBN: 978615-5224-67-6

[34] E. Kurucz - G. Antal - M. G. Fári - J. Popp (2014) Cost-effective mass propagation of Virginia Fanpetals (Sida hermaphrodita L. Rusby) from seeds. Environmental Engineering and $\begin{array}{lllll}\text { Management } & \text { Journal, } & 13 & \text { (11) } & \text { pp. }\end{array}$ http://omicron.ch.tuiasi.ro/EEMJ/pdfs/vol13/no11/19_689_Kurucz_14_proof.pdf

[35] G. Antal - E. Kurucz - M. G. Fári - J. Popp (2014) Tissue culture and agamic propagation of winter-frost tolerant 'Longicaulis' Arundo donax L. Environmental Engineering and Management Journal, 13 (11) pp. 2709-2715. http://omicron.ch.tuiasi. ro/EEMJ/pdfs/vol13/no11/Full/1_671_Antal_14.pdf

[36] G. Antal - E. Kurucz - M. G. Fári (2015) Alternatives of bioenergy feedstock production based on promising new perennial rhizomatous grasses and herbaceous semishrub crops in Hungary. 
International Review of Applied Sciences and Engineering, 6 (1) pp. 41-46. doi: http://dx.doi.org/10.1556/1848.2015.6.1.6

[37] C. Mariani - R. Cabrini - A. Danin - P. Piffanelli - A. Fricano - S. Gomarasca - M. Dicandilo - F. Grassi - C. Soave (2010) Origin, diffusion and reproduction of the giant reed (Arundo donax L.): a promising weedy energy crop. Annals of Applied Biology, 157 (2), pp. 191-202. doi:10.1111/j.1744-7348.2010.00419.x

[38] L. Corno - R. Pilu - F. Adani (2014) Arundo donax L.: a non-food crop for bioenergy and biocompound production. Biotechnology Advances, 32 (8) pp. 1535-1549. http://dx.doi.org/10.1016/j.biotechadv.2014.10.006

[39] R. Pilu - F. C. Badone - L. Michela (2012) Giant reed (Arundo donax L.): A weed plant or a promising energy crop? African Journal of Biotechnology, 11 (38) pp. 9163-9174. doi: $10.5897 /$ AJB11.4182

[40] T. Alshaal- É. Domokos-Szabolcsy - L. Márton - M. Czakó - J. Kátai - P. Balogh - N. Elhawat H. El-Ramady - M. Fári (2013) Phytoremediation of bauxite-derived red mud by giant reed. Environmental Chemistry Letters, 11 (3) pp. 295-302. doi:10.1007/s10311-013-0406-6

[41] N. Elhawat - T. Alshaal - É. Domokos-Szabolcsy - H. El-Ramady - L. Márton - M. Czakó - J. Kátai - P. Balogh - A. Sztrik - M. Molnár (2014) Phytoaccumulation potentials of two biotechnologically propagated ecotypes of Arundo donax in copper-contaminated synthetic wastewater. Environmental Science and Pollution Research, 21 (12) pp. 7773-7780. doi:10.1007/s11356-014-2736-8

[42] É. Domokos-Szabolcsy - N. A. Alladalla - T. Alshaal - A. Sztrik - L. Márton - H. El-Ramady (2014) In vitro comparative study of two Arundo donax L. ecotypes' selenium tolerance. International Journal of Horticultural Science, 20 (3-4) pp. 119-122.

[43] H. R. El-Ramady - N. Abdalla - T. Alshaal - M. Fári - J. Prokisch - E. A. H. Pilon-Smits - É. Domokos-Szabolcsy (2015a) Selenium phytoremediation by giant reed. Hydrogen Production and Remediation of Carbon and Pollutants, pp. 133-198. Springer.

[44] C. M. J Williams - T. K. Biswas - G. Schrale - J. G. Virtue - S. Heading (2008) Use of saline land and wastewater for growing a potential biofuel crop (Arundo donax L.). Irrigation Australia $2008 \quad$ Conference. http://irrigation.org.au/documents/publicationsresources/conference_papers_2008/200508_Stream3_CMJWilliams.pdf, letöltés dátuma: 2016.09.25.

[45] N. Elhawat - É. Domokos-Szabolcsy - T. Alshaal - M. Molnár - G. Antal - L. Márton - M. G. Fári (2013b) Szomatikus embrió eredetű olasznád (Arundo donax L.) klaszterek in vitro sótürése két ökotípus összehasonlításával. XIX. Növénynemesítési Tudományos Napok, 2013. március 7, Keszthely, pp. 38.

[46] M. Scani (2012) Utopia and Fascist foundation cities, The case of Torviscosa, In: Utopia e controutopie, Palmisano A. L. (Ed), DADA, Rivista di Antropologia post-globale, 1, Trieste, pp. 308.

[47] H. Akahoshi - E. Obataya (2015) Effects of wet-dry cycling on the mechanical properties of Arundo donax L. used for the vibrating reed in woodwind instruments. Wood Science and Technology, 49 (6), pp. 1171-1183. doi:10.1007/s00226-015-0760-6

[48] A. M. Gabarrón - J. A. F. Yepes - J. J. P. Pérez - J. M. B. Serna - L. C. Arnold - F. J. S. Medrano (2014) Increase of the flexural strength of construction elements made with plaster (calcium sulfate dihydrate) and common reed (Arundo donax L.). Construction and Building Materials, 66, pp. 436-441. http://dx.doi.org/10.1016/ j.conbuildmat.2014.05.083 
[49] A. Monti - N. Di Virgilio - G. Venturi, (2008) Mineral composition and ash content of six major energy crops. Biomass and Bioenergy, 32 (3) pp. 216-223. http://dx.doi.org/ 10.1016/j.biombioe.2007.09.012

[50] N. Nassi o Di Nasso - L. G. Angelini - E. Bonari (2010) Influence of fertilisation and harvest time on fuel quality of giant reed (Arundo donax L.) in central Italy. European Journal of Agronomy, 32 (3) pp. 219-227. http://dx.doi.org/10.1016/j.eja.2009.12.001

[51] N. Nassi o Di Nasso - N. Roncucci - F. Triana - C. Tozzini - E. Bonari (2011) Productivity of giant reed (Arundo donax L.) and miscanthus (Miscanthus x giganteus Greef et Deuter) as energy crops: growth analysis. Italian Journal of Agronomy, 6 (3) pp. 141-147. doi: 10.4081/ija.2011.e22

[52] N. Nassi o Di Nasso - N. Roncucci - E. Bonari - G. Venturi (2013) Giant reed (Arundo donax L.) as energy crop in Central Italy: a review. Italian journal of Agronomy. 8 (s1) e3, pp. 10-17.

[53] L. G. Angelini - L. Ceccarini - N. Nassi o Di Nasso - E. Bonari, (2009) Comparison of Arundo donax L. and Miscanthus x giganteus in a long-term field experiment in Central Italy: analysis of productive characteristics and energy balance. Biomass and Bioenergy, 33 (4) pp. 635-643. http://dx.doi.org/10.1016/j.biombioe.2008.10.005

[54] A. Schievano - G. D’Imporzano - L. Corno - F. Adani - C. F. Badone - S. R. Pilu (2012) Piú biogas a costi inferiori con Arundo o doppia coltura. L'Informatore Agrario, 25. pp. 21-25.

[55] L. Corno - R. Pilu - F. Tambone - B. Scaglia - F. Adani (2015) New energy crop giant cane (Arundo donax L.) can substitute traditional energy crops increasing biogas yield and reducing $\begin{array}{lllll}\text { costs. Bioresource } & \text { Technology, 191, pp. }\end{array}$ doi:http://dx.doi.org/10.1016/j.biortech.2015.05.015

[56] Arundo Italia Ltd. [Online]: http://www.Arundo.it/index.php/chi-siamo?id=31, letöltés dátuma: 2017.12.12.

[57] A. A. Jaradat (2010) Genetic resources of energy crops: Biological systems to combat climate change. Australian Journal of Crop Science, 4 (5) pp. 309-323.

[58] D. Chiaramonti - A. Giovanni - R. Janssen - R. Mergner (2013) Lignocellulosic ethanol process and demonstration, Handbook, Part I. WIP Renewable Energies, Munich, Germany, ISBN 393338-32-9, 139 p. 